\title{
DAMPAK PERUBAHAN PENGGUNAAN LAHAN TERHADAP RESPON HIDROLOGIS DI DAS ASAHAN
}

\author{
Landuse Change Impact on Hydrologic Responses in Asahan Watershed
}

\author{
Ahmad Dany Sunandar ${ }^{1}$, Endang Suhendang ${ }^{2}$, Hendrayanto ${ }^{2}$, \\ I Nengah Surati Jaya ${ }^{2}$ dan/and Marimin ${ }^{3}$ \\ ${ }^{1}$ Balai Penelitian dan Pengembangan Lingkungan Hidup dan Kehutanan, Aek Nauli, Indonesia \\ Jl. Raya Parapat Km 10,5 Ds. Sibaganding, Parapat, Sumatera Utara, Indonesia \\ Tlp. (0625) 41659; Fax. (0625) 891963 \\ ${ }^{2}$ Fakultas Kehutanan Institut Pertanian Bogor \\ Jl. Lingkar Akademik Kampus IPB Dramaga Bogor 16680, Jawa Barat, Indonesia \\ Tlp. (0251) 8621677, Fax. (0251) 8621256 \\ ${ }^{3}$ Fakultas Teknologi Pertanian Institut Pertanian Bogor \\ Jl. Meranti, Kampus IPB Dramaga Bogor 16680, Jawa Barat, Indonesia \\ Tlp. (0251) 8629354; 8629364, Fax. (0251) 8629352 Email: faperta@ipb.ac.id
}

Email: sunandar_dany@yahoo.com; e_suhendang@yahoo.com; hendrayanto@gmail.com; ins-jaya@cbn.net.id

Tanggal diterima: 30 April 2016; Tanggal direvisi: 6 Mei 2016; Tanggal disetujui:

\begin{abstract}
ABTRACT
Land use change is a dynamic process of human activity and these changes will affect hydrological response of a watershed. The research aimed to identify hydrological responses of Asahan watershed due to land use change. Post classification image analysis method was applied to analyze landsat image to detect land use change. SWAT model was built using land use data, soil type and daily climate data from 1985-2010. The results showed that landuse change were more prevalent in non forest land while the forest was relatively fixed. Optimum land use was shown in 2010, indicated with the lowest surface run off and the highest water yield. Improved hydrological response of Asahan Watershed throughout 1985-2010 occured due to relatively fixed area of forest cover, reduction of barrend land and shrubs and addition of plantation area.
\end{abstract}

Keywords: Surface run off, landuse, watershed, water yield

\begin{abstract}
ABSTRAK
Perubahan penggunaan lahan merupakan proses yang dinamis dari aktivitas manusia dan perubahan ini akan berpengaruh terhadap respon hidrologi dalam suatu Daerah Aliran Sungai (DAS). Penelitian ini bertujuan untuk mengidentifikasi respon hidrologi DAS Asahan akibat perubahan penggunaan lahan yang terjadi di DAS Asahan. Analisis perubahan penggunaan lahan dilakukan melalui analisis citra Landsat dengan metode post classification image analysis. Model SWAT dibangun dengan data penggunaan lahan, data jenis tanah dan iklim harian antara tahun 1985-2010. Hasil penelitian menunjukkan bahwa perubahan lahan lebih banyak terjadi di lahan non hutan sedangkan lahan hutan relatif tetap. Penggunaan lahan optimal terlihat pada tahun 2010 yang ditunjukkan dengan aliran permukaan yang paling kecil dan hasil air yang tinggi. Perbaikan respon hidrologis DAS Asahan dari tahun 1985-2010 terjadi karena luas hutannya relatif tetap, berkurangnya luas lahan terbuka dan semak belukar serta bertambahnya luas lahan perkebunan.
\end{abstract}

Kata kunci: Aliran permukaan, daerah Aliran Sungai, hasil air, penggunaan lahan

\section{PENDAHULUAN}

Penggunaan lahan dan sistem hidrologi merupakan suatu sistem yang saling terkait dimana penggunaan lahan mengontrol prosesproses yang terkait dengan intersepsi curah hujan dan evapotranspirasi yang berpengaruh terhadap penyimpanan dan aliran air (Nyeko et al., 2012).
Penggunaan lahan dan perubahannya merupakan salah satu faktor kritis yang mempengaruhi komponen dalam hidrologi seperti evaporasi, aliran permukaan, infiltrasi dan pengisian air permukaan (Ozturk et al., 2013). Perubahan penggunaan lahan juga akan berdampak pada suplai air dengan merubah proses-proses hidrologi seperti infiltrasi, pengisian air tanah, 
aliran dasar dan limpasan permukaan (run off) (Lin et al., 2007) dan kualitas air, habitat perairan dan saluran serta morfologi banjir (James \& Lecce, 2013).

Pengaruh penutupan lahan (seperti hutan) terhadap respon hidrologi dalam DAS sudah banyak dibuktikan melalui berbagai penelitian (Mubarok et al., 2015; Dasanto et al., 2014; Zhang \& Wei, 2013; Winkler et al., 2010). Perubahan tutupan lahan hutan dan faktor manajemen yang diaplikasiakan pada suatu kawasan hutan akan merubah respon hidrologi dalam suatu DAS (Pike et al., 2010; Jones et al., 2009). Di Indonesia, penelitian mengenai pengaruh perubahan penggunaan lahan terhadap respon hidrologis telah banyak dilakukan. Anwar et al. (2011) menyatakan bahwa penurunan penutupan lahan hutan di DAS Barito Hulu sebanyak 9,51\% dari kondisi semula dapat meningkatkan hasil air, evapotranspirasi dan erosi berturut-turut sebesar $8,52 \%, 5,94 \%$ dan 1,73 ton per ha per tahun serta simpanan air menurun sebesar $14,46 \%$. Prasena \& Srestha (2013) menyatakan bahwa berkurangnya lahan kebun campuran menjadi lahan pemukiman sebanyak 4,28\% dan meningkatkan limpasan antara 3,42\%-4,67\%.

Salah satu model untuk menduga dampak perubahan penggunaan lahan terhadap respon hidrologi adalah Soil and Water Assessment Tool (SWAT) (Dechmi et al., 2012). Untuk membangun sebuah model menggunakan SWAT, diperlukan data spasial dan tabular yang akan digabung ke dalam model. Data spasial yang dibutuhkan adalah data Digital Elevation Model (DEM) untuk membentuk aliran dan peta kelas lereng, data jenis tanah dan data tutupan atau penggunaan lahan. Data iklim dalam bentuk tabular kemudian digabungkan untuk membangun model. Dalam aplikasinya, SWAT membagi sebuah DAS menjadi beberapa sub DAS yang dihubungkan dengan jaringan sungai dan Hydrologic Response Unit (HRU) yang dibangun dari kombinasi tutupan lahan, jenis tanah dan lereng pada setiap sub DAS (Nobert \& Jeremiah, 2012). Dalam SWAT, kalibrasi merupakan upaya untuk menghasilkan parameter model yang lebih baik, sesuai dengan kondisi DAS setempat, sehingga bisa mengurangi ketidakpastian prediksi (Arnold et al., 2012).

Aplikasi SWAT dalam berbagai keperluan terkait dengan hidrologi dalam DAS di Indonesia telah banyak dilakukan diantaranya untuk evaluasi kinerja DAS dan simulasi konservasi di sub DAS Tabung, Siak (Fajri et al., 2016), pengelolaan DAS Cisadane (Junaidi \& Tarigan, 2012), kajian respon perubahan penggunaan lahan terhadap karakteristik hidrologi di DAS Cirasea (Yusuf, 2010) dan untuk pengelolaan lahan terbaik di sub DAS Ciliwung Hulu (Yustika, 2013). Penelitian ini bertujuan untuk mengetahui dampak perubahan penggunaan lahan terhadap respon hidrologis (aliran permukaan, debit, aliran dasar dan hasil air) di DAS Asahan yang terjadi antara tahun 1990-2010.

\section{METODOLOGI}

\section{A. Waktu dan Tempat Penelitian}

Penelitian dilaksanakan pada bulan November 2013 sampai dengan Januari 2014. Penelitian ini dilakukan di DAS Asahan, Provinsi Sumatera Utara yang terletak antara 99,03-99,96 BT dan 2,40-3,04 BT (Gambar 1). Luas DAS Asahan berdasarkan hasil delineasi menggunakan model SWAT adalah 2.833,86 $\mathrm{km}^{2}$ dengan panjang sungai utama mencapai $170 \mathrm{~km}$. DAS Asahan mempunyai topografi yang curam di sekitar hulu, tetapi landai di tengah hingga ke hilir dan mempunyai elevasi mulai dari $0 \mathrm{~m}$ dpl hingga ketinggian $2.100 \mathrm{~m}$ dpl. Penggunaan lahan didominasi oleh pertanian lahan kering dan perkebunan dengan dengan komoditas utama berupa kelapa sawit dan karet. Curah hujan antara 1.924-3.406 mm per tahun (berdasarkan data tahun 1985-2010).

\section{B. Bahan dan Alat}

Bahan yang digunakan dalam penelitian berupa data spasial dan data tabular. Data spasial yang digunakan adalah data hasil analisis citra Landsat yang menampilkan citra penutupan lahan tahun 1990 (path 128, row 58, date acquisition 18 Desember 1990), 2002 (path 128, row 58, date acquisition 2 Februari 2002) dan 2010 (path 128, row 58, date acquisition 10 Februari 2010), data DEM (Digital Elevation Model), data jenis tanah dan atributnya (jumlah lapisan, ketebalan setiap lapisan, berat jenis, fraksi) yang diperoleh dari Pusat Penelitian Tanah dan Agroklimat dan hasil pengamatan serta data iklim (hujan harian, suhu maksimumminimum harian, kelembaban relatif, lama penyinaran matahari, kecepatan angin rata-rata harian) yang diperoleh dari Badan Meteorologi Geofisika dan Klimatologi untuk stasiun yang berada di DAS Asahan serta sebagai data pembanding dalam proses kalibrasi dan validasi 
adalah data debit sungai di DAS Asahan (data tersedia adalah tahun 1990-2010 minus tahun 2004 dan 2008) yang diperoleh dari Balai Wilayah Sungai II Medan dan Pusat Litbang Pengairan, Kementerian Pekerjaan Umum. Alat yang digunakan adalah komputer dengan software ArcGIS 10.1 dengan tambahan eksteksi SWAT, Global Posistioning System (GPS) dan alat pengambilan contoh tanah.

\section{Metode}

Analisis perubahan penggunaan lahan dilakukan menggunakan citra Landsat yang diperoleh tahun akuisisi 1990, 2002 dan 2010 dianalisis dengan menggunakan program ERDAS Imagine dengan metode visual delineation. Penentuan penutupan atau penggunaan lahan didasarkan pada panduan yang dikeluarkan oleh Badan Planologi Kehutanan (2008) dan membagi penutupan atau penggunaan lahan menjadi 11 kelas, yaitu hutan campuran, perkebunan, pertanian, pemukiman, tanah terbuka, sawah, mangrove, lahan basah tidak berhutan, rawa, semak belukar dan tubuh air. Untuk mengetahui perubahan yang terjadi dilakukan post classification image analysis dengan melakukan tumpang susun dan kemudian diidentifikasi dan dikuantifikasi perubahan yang terjadi.

Pembangunan model hidrologi menggunakan SWAT dilakukan dalam beberapa tahapan. Tahapan pertama adalah pendefinisian areal tangkapan dan deliniasi batas dengan menggunakan data DEM dan masking (penentuan batas area). Pada tahapan ini juga dilakukan pembentukan sub DAS yang dalam penelitian ini area minimumnya diatur pada 10.000 ha dan ditentukan titik outlet DAS. Tahapan berikutnya adalah pembentukan HRU yang merupakan hasil tumpang susun antara penggunaan atau penutupan lahan, jenis tanah dan kelas lereng. Batas atau threshold yang digunakan adalah persentase luas area dan digunakan masing-masing untuk penggunaan atau penutupan lahan, jenis tanah dan kelas lereng masing-masing adalah $10 \%$, $10 \%$ dan $5 \%$.

Pemasukan data iklim menjadi tahapan berikutnya dimana data iklim hasil pengolahan menjadi data input dalam weather generator ("wgn") sebagai pembangkit data iklim dari Stasiun Iklim Sampali, Medan. Data curah hujan harian dan suhu maksimum-minimum harian berasal dari lima stasiun pengukur hujan. Setelah data iklim terinput maka model SWAT dapat

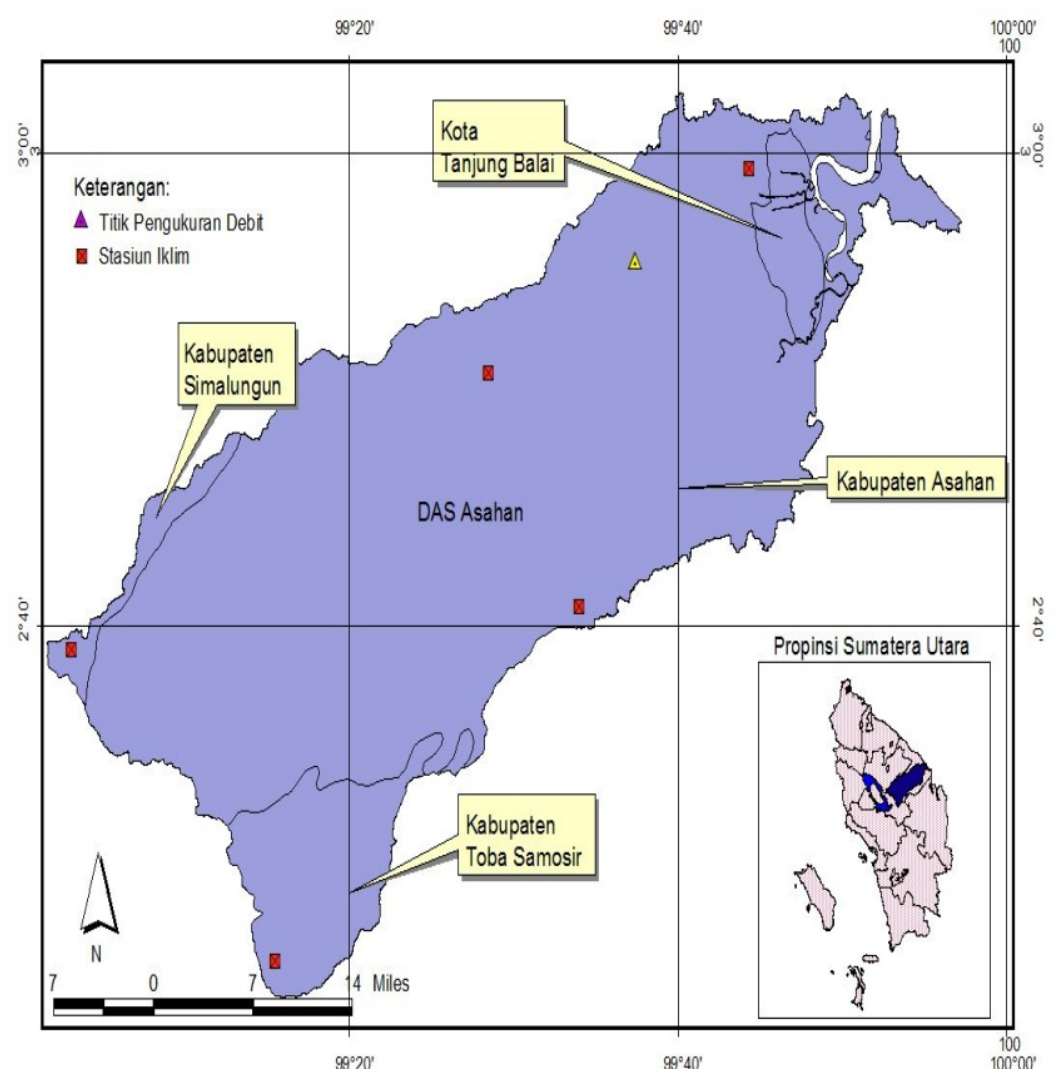

Gambar (Figure) 1. Lokasi penelitian (Research location) 
disimulasikan. Dalam simulasi ini, data penggunaan atau penutupan lahan yang digunakan adalah data tahun 2010 .

Analisis sensitivitas dan kalibrasi model SWAT yang digunakan dalam penelitian ini menggunakan program SWAT CUP SUFI-2 yang merupakan program kalibrasi semi automatis (Abbaspour, 2011). Penentuan parameter yang dikalibrasi didasarkan pada hidrograf yang terbentuk hasil simulasi SWAT yang dibandingkan dengan data debit hasil pengukuran. Kalibrasi menggunakan data debit rata-rata bulanan dari Januari 2009 sampai dengan Agustus 2010 dan data penutupan lahan tahun 2010 dengan jumlah iterasi atau pengulangan sebanyak 300 kali dan diharapkan menghasilkan nilai NSE yang mendekati 1. Menurut Moriasi et al. (2007) nilai NSE adalah antara 0-1, apabila nilai NSE mendekati 0 berarti rata-rata nilai observasi lebih baik dari nilai simulasi dan hal ini mengindikasikan kinerja model yang tidak dapat diterima. Proses kalibrasi ini akan menghasilkan nilai parameter terbaik dan parameter yang sensitif terhadap perubahan nilainya. Nilai parameter yang terbaik kemudian akan divalidasi untuk menguji kehandalan model yang dalam penelitian ini dilakukan untuk data debit tahun 1990-1991 dan data penggunaan lahan tahun 1990.

Untuk menganalisis dampak perubahan penggunaan luasan lahan terhadap respon hidrologis di DAS Asahan, digunakan dua metode. Metode pertama melalui analisis deskriptif dengan membandingkan curah hujan dengan debit (observasi) yang dihasilkan. Metode kedua adalah melalui simulasi menggunakan model SWAT, untuk mengidentifikasi dampak perubahan penggunaan lahan terhadap aliran permukaan, aliran dasar dan hasil air.

\section{HASIL DAN PEMBAHASAN}

Berdasarkan hasil analisis citra satelit, perubahan luasan penutupan lahan terjadi di seluruh tipe penutupan lahan. Hasil tabulasi perubahan yang terjadi dapat dilihat pada Tabel 1.

Tabel (Table) 1. Luas masing-masing tutupan lahan dan perubahannya (ha) (Coverage areas of land use and its change) (ha)

\begin{tabular}{|c|c|c|c|c|c|c|c|}
\hline \multirow{2}{*}{ No } & \multirow{2}{*}{$\begin{array}{l}\text { Tutupan lahan } \\
\text { (Landuse type) }\end{array}$} & \multicolumn{6}{|c|}{ Luas (Areas) $($ ha $)$} \\
\hline & & 1990 & 2002 & 2010 & $1990-2002$ & $2002-2010$ & $1990-2010$ \\
\hline 1 & Hutan lahan kering & 47.352 & 47.353 & 47.623 & 0 & 270 & 271 \\
\hline 2 & $\begin{array}{l}\text { (Dryland forest) } \\
\text { Hutan lahan basah } \\
\text { (Wetland forest })\end{array}$ & 468 & 469 & 451 & 1 & -18 & -17 \\
\hline 3 & Pemukiman (Urban) & 2.465 & 2.469 & 2.746 & 4 & 277 & 281 \\
\hline 4 & Perkebunan (Plantation) & 71.413 & 70.703 & 78.347 & -710 & 7.644 & 6.934 \\
\hline 5 & $\begin{array}{l}\text { Pertanian lahan kering } \\
\text { (Dryland agriculture) }\end{array}$ & 112.167 & 110.884 & 116.183 & -1.283 & 5.299 & 4.016 \\
\hline 6 & Rawa (Swamp) & 397 & 365 & 235 & -32 & -130 & -162 \\
\hline 7 & Sawah (Paddy field) & 1.451 & 1.871 & 3.172 & 420 & 1.301 & 1.721 \\
\hline 8 & Semak/belukar (Bush) & 27.965 & 22.025 & 21.171 & -5.940 & -854 & -6.794 \\
\hline 9 & $\begin{array}{l}\text { Tanah terbuka } \\
\text { (Barrend land) }\end{array}$ & 3.715 & 14.413 & 5.153 & 10.698 & -9.260 & 1.438 \\
\hline 10 & Tubuh air (Water body) & 3.390 & 3.390 & 3.366 & 0 & -24 & -25 \\
\hline 11 & $\begin{array}{l}\text { Vegetasi rawa } \\
\text { (Non forest swamp vegetation) }\end{array}$ & 10.607 & 7.437 & 2.922 & -3.170 & -4.515 & -7.685 \\
\hline
\end{tabular}

Sumber (Source): Hasil interpretasi citra (Image interpretation result) 
Perubahan luas terbesar adalah perkebunan yang bertambah hingga 6.934 ha dan pertanian lahan kering seluas 4.016 ha. Penambahan ini karena banyaknya perkebunan baru yang dibangun seiring dengan naiknya harga komoditas perkebunan. Perluasan areal perkebunan sebagian besar berasal dari kawasan hutan lahan basah, terutama hutan rawa dan semak belukar. Perubahan penggunaan lahan lainnya yang cukup besar adalah sawah dan pertanian lahan kering.

Penambahan sawah diduga karena adanya saluran irigasi, dimana dalam rencana tata ruang wilayah Kabupaten Asahan. Penambahan areal irigasi menjadi salah satu fokus pembangunan wilayah (Kabupaten Asahan, 2013). Keberadaan lahan hutan di DAS Asahan relatif tetap, hanya mengalami penambahan 271 ha, yang diduga berasal dari hutan tanaman karena hutan tanaman dalam penelitian ini dimasukkan pada katagori hutan lahan kering. Untuk melihat distribusi perubahan penggunaan lahan yang terjadi di DAS Asahan dapat dilihat pada Tabel 2.

Pada periode perubahan antara tahun 19902002, perubahan terbesar terjadi dari semak belukar yang berubah menjadi tanah terbuka dan perkebunan menjadi tanah terbuka. Hal ini terjadi karena adanya masa pergiliran tanaman di lahan pertanian yang terdeteksi dalam citra sebagai tanah terbuka. Begitu juga di areal perkebunan, diduga adanya masa replanting, sehingga areal tersebut merupakan areal perkebunan tetapi yang terlihat dalam citra adalah sebagai tanah terbuka. Periode tahun 2002-2010, perubahan terbesar dari tanah terbuka dan vegetasi rawa menjadi lahan perkebunan serta dari perkebunan menjadi lahan pertanian.

Hutan lahan kering bertambah dari tahun 1990 sampai 2010 sebesar 271 ha. Meskipun di sisi lain, ada lahan hutan yang berubah menjadi tanah terbuka tetapi perubahan dari pertanian lahan kering yang berubah menjadi hutan lebih besar seperti yang terlihat pada Tabel 2 . Pertambahan areal hutan terjadi karena dalam klasifikasi hutan lahan kering termasuk hutan tanaman. Adanya penanaman baru di lahan hutan tanaman menyebabkan bertambahnya hutan lahan kering. Selain itu, daerah dengan penutupan lahan hutan tidak banyak berubah karena berada di daerah dengan topografi yang relatif curam dan mempunyai elevasi yang relatif tinggi

Tabel(Table)2. Distribusi perubahan penggunaan lahan antara tahun 1990-2010 (Landuse change distribution from 1990-2010)

\begin{tabular}{|c|c|c|c|c|c|c|c|c|c|c|c|}
\hline \multirow{2}{*}{$\begin{array}{l}\text { Tutupan lahan } \\
\text { (Landuse type) }\end{array}$} & \multicolumn{11}{|c|}{$\begin{array}{l}\text { Luas perubahan penggunaan lahan tahun 1990-2010 (ha) } \\
\text { (Landuse change areas in } 1990 \text { to 2010) (ha) }\end{array}$} \\
\hline & HLK & HLB & 3 PMKM & PKBN & PLKR & Rawa & Sawah & S/B & TTBK & T. AIR & VGRW \\
\hline $\begin{array}{l}\text { Hutan lahan kering } \\
\text { (Dryland forest) }\end{array}$ & - & - & - & - & - & - & - & - & 419 & - & - \\
\hline $\begin{array}{l}\text { Hutan lahan basah } \\
\text { (Wetland forest) }\end{array}$ & - & - & 10 & - & - & - & - & - & 7 & - & - \\
\hline Pemukiman (Urban) & - & - & - & - & - & - & - & - & - & - & - \\
\hline $\begin{array}{l}\text { Perkebunan } \\
\text { (Plantation) }\end{array}$ & - & - & - & - & 7.869 & - & - & 199 & 3.418 & - & - \\
\hline $\begin{array}{l}\text { Pertanian lahan kering } \\
\text { (Dryland agriculture) }\end{array}$ & 605 & - & 401 & 2.561 & - & - & 142 & 144 & 540 & - & - \\
\hline Rawa (Swamp) & - & - & - & 22 & 153 & - & - & - & & - & - \\
\hline Sawah (Paddy field) & - & - & - & 184 & - & - & - & - & - & - & - \\
\hline Semak belukar (Bush) & 85 & - & - & 6.016 & 854 & - & 1.447 & - & 9 & - & - \\
\hline $\begin{array}{l}\text { Tanah terbuka } \\
\text { (Barrend land) }\end{array}$ & - & - & - & 901 & 1.123 & - & - & 1.259 & - & - & - \\
\hline Tubuh air (Water body) & - & 1 & 1 & 4 & 13 & - & - & 5 & & - & 2 \\
\hline $\begin{array}{l}\text { Vegetasi rawa } \\
\text { (Non forest swamp } \\
\text { vegetation) }\end{array}$ & - & - & - & 7.930 & 1.096 & - & 418 & & 362 & - & - \\
\hline
\end{tabular}

Sumber (Source): Hasil pengolahan citra Landsat (Landsat image processing result)

Keterangan(Remarks): HLK: Hutan lahan kering (Dryland forest); HLB: Hutan lahan basah (Wetland forest); PMKM: Pemukiman (Urban); PKBN: Perkebunan (Plantation); PLKR: Pertanian lahan kering (Dryland agriculture); S/B: Semak/belukar (Bush); T. Air: Tubuh air (Water body); TTBK: Tanah terbuka (Barrend land); VGRW: vegetasi rawa (non hutan) (Swamp forest) 
dengan aksesibilitas yang terbatas, sehingga dapat terjaga keutuhannya. Hal ini sejalan dengan penelitian dari Freitas et al. (2010) yang menyatakan bahwa topografi berpengaruh terhadap penggunaan lahan dan dinamika hutan. Sisi hukum, daerah ini juga merupakan kawasan hutan lindung, sehingga secara hukum lebih dapat terlindungi.

Hasil perhitungan diperoleh bahwa sebelum kalibrasi nilai $\mathrm{R}^{2}=0,76$ dengan $\mathrm{NSE}=0,64$. Meskipun ini sudah cukup baik, namun masih bisa lebih baik lagi dengan proses kalibrasi. Proses kalibrasi dilakukan dengan membagi waktu simulasi menjadi tiga bagian, yaitu warm up period, peride kalibrasi dan periode validasi (Arnold et al., 2012). Parameter yang digunakan dalam kalibrasi adalah mencakup aliran (gw), aliran permukaan dan routing serta HRU. Parameter yang sensitif untuk keluaran model pada proses kalibrasi meliputi parameter yang sensitif terhadap debit aliran, yang meliputi metode penelusuran air pada aliran sungai (routing), parameter baseflow, parameter pada saluran sungai utama, parameter pada tingkat sub DAS dan HRU. Input parameter yang digunakan dapat dilihat pada Tabel 3 dan kalibrasi dilakukan menggunakan Sufi-2 SWAT-CUP.

Hasil kalibrasi dengan menggunakan SWATCUP memberikan hasil yang baik yaitu nilai $\mathrm{R}^{2}=$ 0,89 dan NSE $=0,88$. Hal ini menunjukkan bahwa model SWAT sudah cukup baik dan dapat digunakan untuk validasi. Proses validasi dilakukan dengan menggunakan nilai parameter hasil kalibrasi dan dilakukan untuk penutupan lahan tahun 1990 dan data debit bulanan tahun 19901991.

Validasi merupakan langkah evaluasi terhadap model dan bertujuan untuk membuktikan bahwa model yang dibangun dapat diduga pada sebagian besar DAS. Apabila aliran permukaan ini berubah akan berdampak pada perubahan seluruh komponen dalam kesetimbangan hidrologis (Arnold et al., 2012). Recharge_dp adalah koefisien perkolasi dari akuifer. Jika nilai Recharge $d p$ ditingkatkan akan berpengaruh pada peningkatan pengisian akuifer dalam (Abraham et al., 2007). Perbedaan antara debit hasil observasi dengan debit simulasi sebelum dan sesudah kalibrasi dapat dilihat pada Gambar 2 dan Gambar 3.

Perubahan penggunaan lahan dilihat dari aspek hidrologi, berpengaruh langsung terhadap karakteristik penutupan lahan, sehingga akan mempengaruhi sistem tata air DAS. Fenomena ini ditunjukkan oleh karakteristik DAS yang dapat dikenali melalui produksi air, erosi dan sedimen. Perubahan pola debit terhadap perubahan penggunaan lahan di DAS Asahan dapat dilihat pada Tabel 4 dan grafik hubungan curah hujan dengan debit pada masing-masing penggunaan lahan dapat dilihat pada Gambar 4.

Berdasarkan Gambar 4, terdapat perbedaan pola pada debit untuk masing-masing tahun penggunaan lahan. Penggunaan lahan tahun 1990 menunjukkan bahwa curah hujan yang tinggi relatif tidak berpengaruh terhadap debit yang dihasilkan. Hal ini ditunjukkan oleh penye-baran debit yang mendekati $50 \mathrm{~mm}$ pada kondisi curah hujan yang meningkat.

Berbeda dengan penggunaan lahan tahun 2002, dimana ada kecenderungan kenaikan debit seiring dengan kenaikan curah hujan meskipun pada curah hujan 44,71 mm menghasilkan debit $41,2 \mathrm{~mm}$ (pada bulan Januari 2002). Ini dikarenakan curah hujan yang relatif lebih sedikit pada tahun 2002, sehingga kenaikan curah hujan direspon dengan positif oleh debit. Pada penggunaan lahan tahun 2010, debit yang dihasilkan mempunyai pola yang hampir sama dengan penggunaan lahan pada tahun 1990. Namun debit pada penggunaan lahan tahun 2010 relatif lebih tinggi dan cenderung naik lebih tinggi seiring dengan kenaikan curah hujan dibandingkan penggunaan lahan tahun 1990.

Besaran debit yang relatif stabil pada penggunaan lahan tahun 1990 dan 2010 disebabkan

Tabel (Table) 3. Parameter yang digunakan dalam kalibrasi (Parameters used in calibration process)

\begin{tabular}{lcccrr}
\hline $\begin{array}{c}\text { Paramater } \\
\text { (Parameters })\end{array}$ & $\begin{array}{c}\text { Nilai akhir } \\
\text { End values })\end{array}$ & $\begin{array}{c}\text { Minimum } \\
(\text { Minimum })\end{array}$ & $\begin{array}{c}\text { Maksimum } \\
\text { (Maximum) }\end{array}$ & t-stat & P-value \\
\hline 1. CN2.mgt & $-4,25$ & -30 & 20 & $-1,60$ & 0,11 \\
2. ALPHA_BNK.rte & 0,715 & 0 & 1 & 2,15 & 0,03 \\
3. RCHRG_DP.gw & 0,565 & 0 & 1 & $-2,86$ & 0,01 \\
4. DEEPST.gw & 2,265 & 0 & 3,000 & $-2,02$ & 0,05 \\
5. GWHT.gw & 17,875 & 0 & 25 & $-1,86$ & 0,07 \\
6. HRU_SLP.hru & 0,369 & 0 & 0,6 & 3,72 & 0,00 \\
\hline
\end{tabular}

Sumber (Source): Hasil pengolahan dengan SWAT-CUP (SWAT-CUP processing result) 


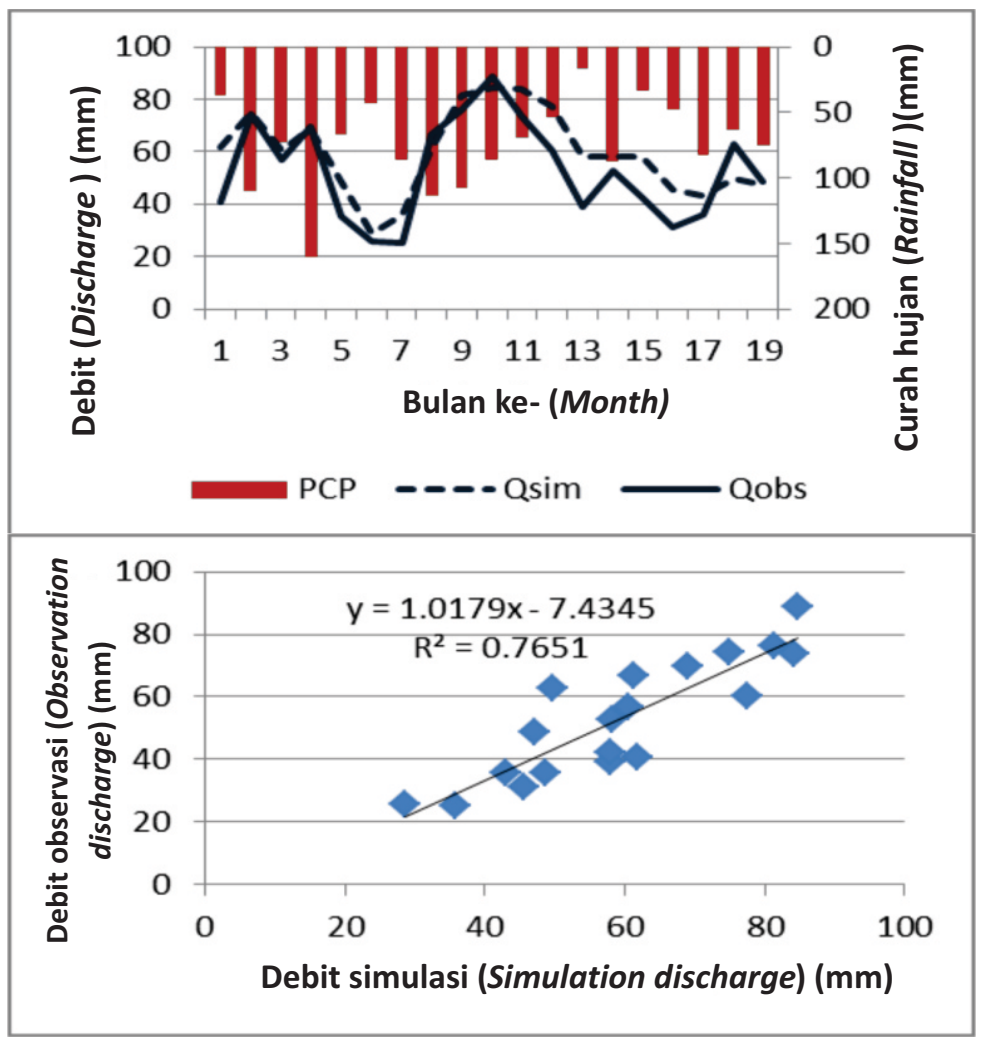

Gambar(Figure)2. Perbandingan data debit observasi dan debit simulasi sebelum kalibrasi (Comparation between observed and simulation discharge before calibration)

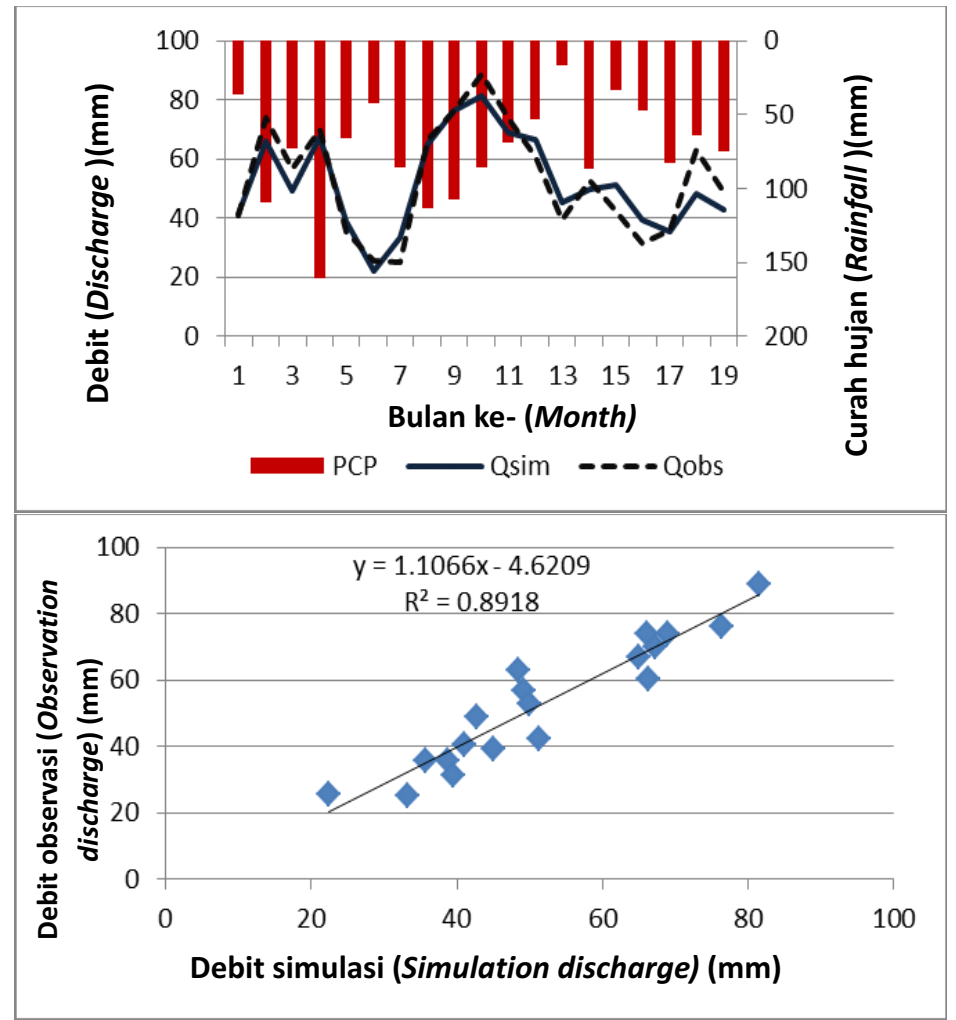

Gambar(Figure)3. Perbandingan data debit observasi dan debit simulasi setelah kalibrasi (Comparation between observed and simulation discharge after calibration) 


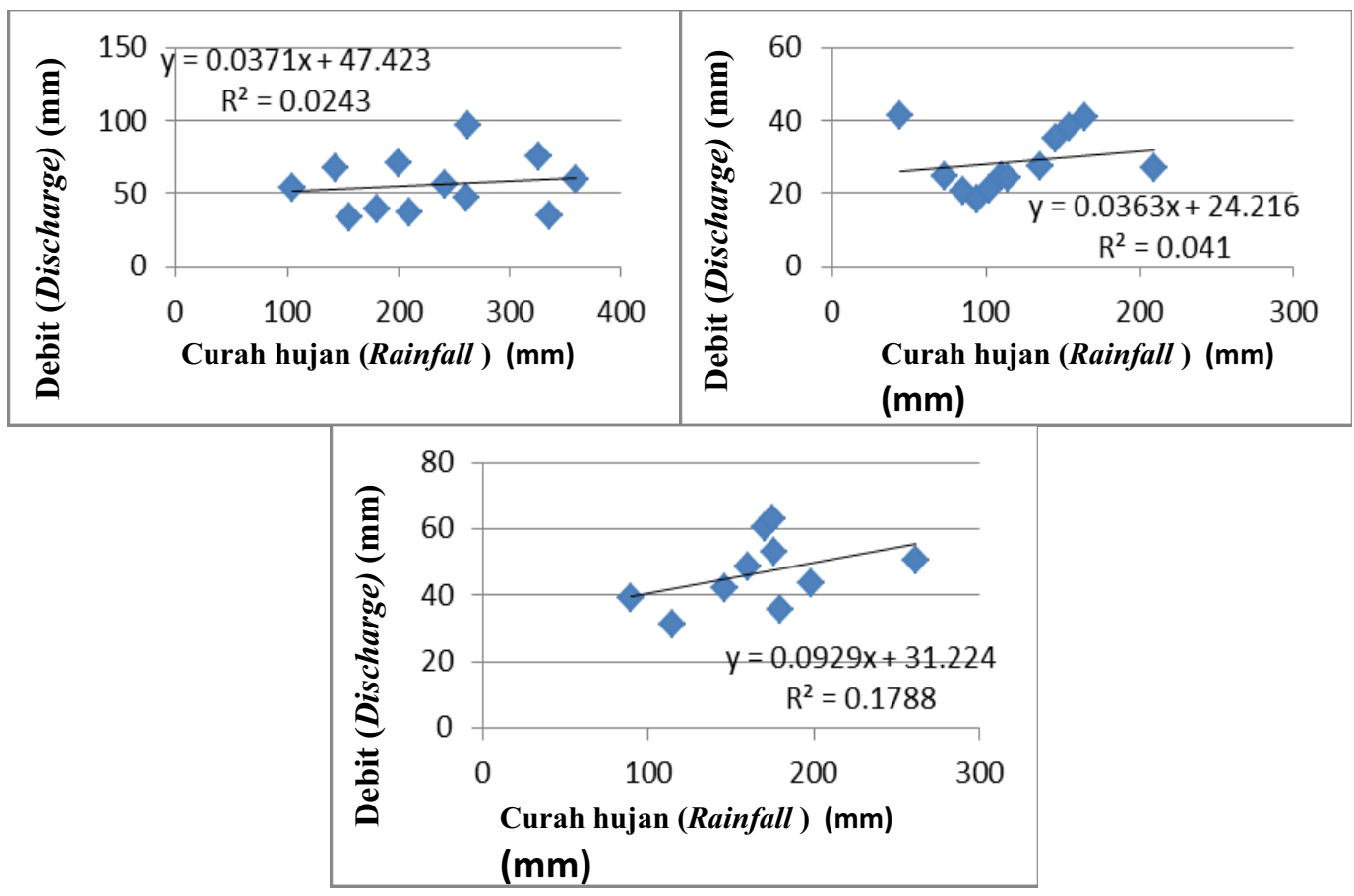

Gambar(Figure) 4. Perbandingan data debit observasi dan debit simulasi sebelum kalibrasi (Comparation between observed and simulation discharge before calibration)

oleh penutupan vegetasi yang relatif merata dengan persentase tanah terbuka yang paling kecil (Tabel 1), sehingga curah hujan yang turun tidak berpengaruh terhadap debit yang dihasilkan. Pada kondisi lahan tertutup vegetasi, seperti pada penggunaan lahan tahun 1990 dan 2010, akan memperbesar daya sangga DAS terhadap debit puncak karena lebih banyak curah hujan yang terinfiltrasi ke dalam tanah dan aliran permukaan akan berkurang. Sebaliknya pada penggunaan lahan tahun 2002 dimana terjadi pengurangan lahan bervegetasi dengan meningkatnya tanah terbuka (Tabel 1). Hal ini dapat menurunkan daya sangga DAS meskipun curah hujan turun akan direspon positif oleh debit.

Tabel(Table) 4. Respon debit terhadap hujan pada masing-masing tahun penggunaan lahan (mm) (Discharge response on rainfall in each land use $(\mathrm{mm})$ )

\begin{tabular}{cccccc}
\hline & \multicolumn{2}{c}{2002} & \multicolumn{2}{c}{2010} \\
\hline $\begin{array}{c}\text { Curah hujan } \\
\text { (Rainfall) }\end{array}$ & $\begin{array}{c}\text { Debit } \\
\text { (Discharge) }\end{array}$ & $\begin{array}{c}\text { Curah hujan } \\
\text { (Rainfall) }\end{array}$ & $\begin{array}{c}\text { Debit } \\
\text { (Discharge) }\end{array}$ & $\begin{array}{c}\text { Curah hujan } \\
\text { (Rainfall) }\end{array}$ & $\begin{array}{c}\text { Debit } \\
\text { (Discharge) }\end{array}$ \\
\hline 143,68 & 67,9 & 44,71 & 41,2 & 170,29 & 60,4 \\
104,81 & 54,4 & 94,56 & 18,4 & 89,38 & 39,2 \\
210,24 & 37,5 & 109,94 & 24,5 & 175,83 & 52,9 \\
336,22 & 34,9 & 145,36 & 34,9 & 146,77 & 42,3 \\
325,55 & 74,7 & 114,82 & 24,1 & 114,64 & 31,4 \\
181,08 & 39,1 & 73,19 & 24,7 & 179,97 & 35,7 \\
260,95 & 46,8 & 101,97 & 21,3 & 174,94 & 62,8 \\
156,38 & 34,1 & 85,77 & 20,7 & 160,56 & 48,8 \\
242,35 & 55,6 & 209,67 & 26,8 & 262,2 & 50,6 \\
263,06 & 97,1 & 164,33 & 40,8 & 198,09 & 43,6 \\
358,94 & 59,8 & 154,92 & 38 & & \\
199,62 & 70,3 & 135,14 & 27,2 & & \\
\hline
\end{tabular}

Sumber (Source): Hasil SWAT (SWAT result) 
Berdasarkan Tabel 4, terlihat bahwa pada penggunaan lahan tahun 1990 dengan curah hujan sebesar $2.783 \mathrm{~mm}$, menghasilkan debit sebesar $672 \mathrm{~mm}$, aliran permukaan 190,2 $\mathrm{mm}$, aliran dasar 296,7 mm serta hasil air 1.083,2 mm. Jika dirasiokan, maka dari total curah hujan yang turun di DAS Asahan selama satu tahun, sebanyak 38,92\% dikonversi menjadi aliran (hasil air) yang merupakan penjumlahan dari aliran permukaan, aliran dasar dan perkolasi. Curah hujan yang membentuk aliran permukaan sebesar 6,83\% dan 10,66\% menjadi aliran dasar (Lampiran 1). Gambaran hubungan antara curah hujan dengan respon hidrologi, pada Gambar 5 terlihat bahwa penggunaan lahan tahun 1990 memberikan respon yang relatif tetap terhadap debit dan aliran dasar sedangkan terhadap aliran permukaan, akan memberikan korelasi yang positif dengan peningkatan curah hujan. Demikian juga untuk hasil air yang berkorelasi positif dengan kenaikan curah hujan.

Pada tahun 2002, curah hujan jauh menurun $(1.434 \mathrm{~mm})$ dan ini direspon dengan debit yang turun menjadi $343 \mathrm{~mm}$, penurunan aliran permukaan menjadi $39 \mathrm{~mm}$, hasil air menjadi 590 mm sedangkan aliran dasar relatif sama (279 $\mathrm{mm})$. Penggunaan lahan pada tahun 2002 ini mengkonversi lebih banyak curah hujan menjadi aliran, yaitu hasil air sebesar $41,12 \%$, aliran dasar $19,98 \%$, debit $23,88 \%$ dan aliran permukaan 2,70\% (Lampiran 1). Hasil ini relatif lebih baik dibandingkan penggunaan lahan tahun 1990, dimana aliran permukaan jauh lebih kecil dengan total hasil air yang lebih besar. Curah hujan yang lebih kecil mampu direspon dengan baik oleh penggunaan lahan yang ada serta struktur geologinya, sehingga menghasilkan aliran permukaan yang relatif lebih kecil dengan hasil air yang lebih banyak.

Pada saat curah hujan relatif rendah, maka terjadinya kelebihan kapasitas infiltrasi akan lebih kecil, sehingga air hujan yang turun lebih banyak terinfiltrasi menjadi aliran dasar. Kondisi ini dapat dilihat seperti pada Gambar 5 (tengah) dimana aliran dasar cenderung naik dan aliran permukaan relatif datar pada kondisi curah hujan kurang dari $200 \mathrm{~mm}$ per bulan. Perbedaan respon terlihat pada saat dimana curah hujan yang relatif tinggi seperti pada tahun 1990 saat curah hujan yang dikonversi menjadi aliran permukaan naik dan aliran dasar menurun (Gambar 5). Pada kondisi penggunaan lahan tahun 1990 ini, air yang berubah menjadi aliran dasar lebih sedikit dibandingkan pada tahun 2002 sedangkan pada tahun 2010, terjadi kenaikan aliran dasar yang paling tinggi dibanding penggunaan lahan sebelumnya, sehingga hasil airnya paling tinggi.

Penggunaan lahan tahun 2010 cenderung mempunyai pola yang mirip dengan tahun 1990 dengan curah hujan mencapai $2.259 \mathrm{~mm}$ yang menghasilkan aliran permukaan $116 \mathrm{~mm}$, aliran dasar $429 \mathrm{~mm}$ dan hasil air $1.93 \mathrm{~mm}$. Pada penggunaan lahan tahun 2010 ini, konversi curah hujan menjadi debit adalah $27,96 \%$ (untuk sepuluh bulan), aliran permukaan $5,14 \%$, aliran dasar 19,01\% dan hasil air 48,33\% (Lampiran 1).

Berdasarkan Gambar 5, terlihat bahwa debit dan aliran cenderung tetap dengen kenaikan curah hujan sedangkan aliran permukaan meskipun naik namun sangat sedikit. Dilihat dari respon hidrologis, hasil yang ditunjukkan oleh penggunaan lahan tahun 2010 relatif lebih baik dari penggunaan lahan tahun 1990 dan 2002. Kondisi geologis yang tetap, namun mampu mengkonversi lebih banyak air hujan menjadi hasil air dengan lebih sedikit aliran permukaan yang terjadi.

Hasil analisis debit dan simulasi SWAT secara umum menunjukkan bahwa penggunaan lahan yang terbaik adalah pada penggunaan lahan tahun 2010, karena pada tahun ini memberikan respon hidrologi yang paling baik. Meskipun demikian, penggunaan lahan yang ada saat ini (diasumsikan tahun 2010) belum merupakan penggunaan lahan terbaik untuk memaksimalkan hasil air dan meminimalkan aliran permukaan yang terjadi di DAS Asahan.

\section{KESIMPULAN DAN SARAN}

\section{A. Kesimpulan}

Perubahan penggunaan lahan yang terjadi di DAS Asahan sebagian besar berada di bagian tengah ke arah hilir DAS dan merupakan lahan pertanian dan perkebunan. Dalam rentang waktu 20 tahun, luas hutan relatif tidak berubah dan perubahan penggunaan lahan yang lebih dinamis terjadi pada areal pertanian lahan kering, perkebunan dan lahan basah. Model SWAT yang dibangun mampu memberikan hasil yang baik dan mampu menggambarkan respon hidrologis akibat dari perubahan penggunaan lahan. Perubahan respon hidrologis ditunjukkan dengan perubahan aliran permukaan, debit, aliran dasar dan hasil air terhadap curah hujan yang turun pada masing-masing tahun penggunaan lahan. Penggunaan lahan pada tahun 2010 mampu menurunkan aliran permukaan, meningkatkan 

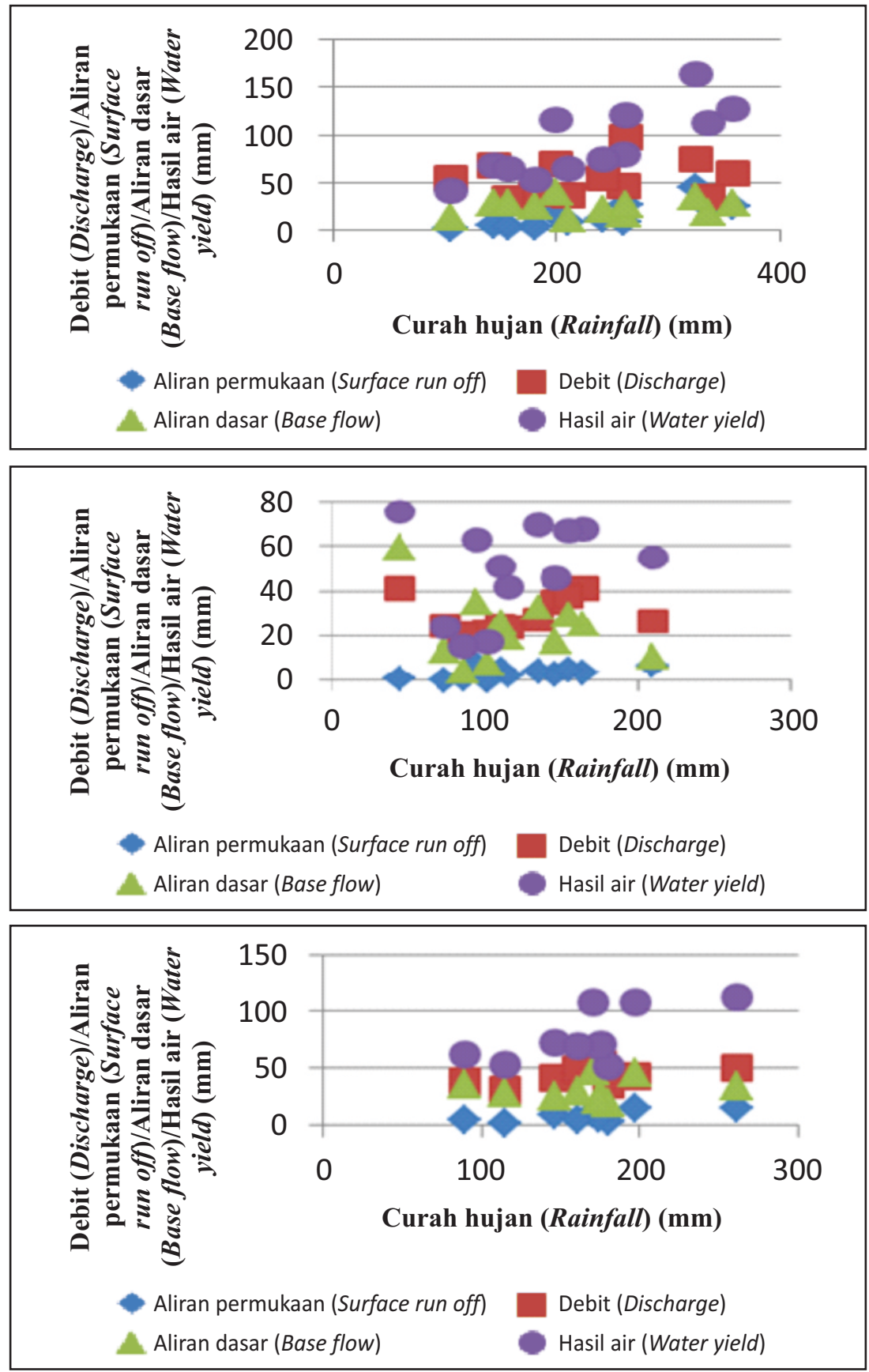

Gambar(Figure) 5. Hubungan curah hujan dengan debit, aliran permukaan, aliran dasar dan hasil air pada penggunaan lahan tahun 1990 (atas), 2002 (tengah), 2010 (bawah) (Relationship among rainfall and discharge, run off, base flow and water yield in 1990 (top), 2002 (middle) and 2010 (bottom) land use)

aliran dasar dan hasil air. Dengan luas hutan yang relatif tetap, penurunan luas lahan terbuka, semak belukar yang diiringi dengan penambahan perkebunan dapat memperbaiki respon hidrologis DAS Asahan. Untuk memperbaiki respon hidrologis DAS Asahan maka perlu dilakukan optimasi penggunaan lahan berdasarkan penggunaan lahan yang ada saat ini.

\section{B. Saran}

Kawasan hutan yang ada di daerah hulu tetap dipertahankan dan perubahan penggunaan lahan ke non hutan perlu dipertimbangkan dengan baik agar tidak terjadi perubahan respon hidrologis yang bersifat merugikan. Optimasi lahan dapat dilakukan untuk mengurangi lahan terbuka dan 
semak belukar dan ditanami dengan tanaman perennial untuk meningkatkan daya sangga DAS pada saat terjadinya surplus air yang turun dalam DAS Asahan.

\section{UCAPAN TERIMA KASIH}

Terima kasih kepada para pembimbing disertasi yang telah mencurahkan waktu perhatian dan pemikirannya hingga selesainya naskah ini. Terima kasih juga penulis ucapkan kepada Balai Penelitian dan Pengembangan Lingkungan Hidup dan Kehutanan Aek Nauli atas bantuannya hingga pengambilan data di lapangan bisa terlaksana. Terima kasih juga untuk teman-teman sesama mahasiswa S3 di IPB yang telah membantu dalam pelatihan SWAT, Pak Iwan Ridwansyah, Mbak Mala dan lainnya, sehingga penulis dapat menyelesaikan naskah tulisan ini.

\section{DAFTAR PUSTAKA}

Abbaspour, K. (2011). SWAT CUP4: SWAT Calibration and uncertainty program - a user manual. Eawag.

Abraham L.Z, Roehrig J., \& Dilnesaw A.C. (2007). Calibration and validation of SWAT hydrological model for Meki Watershed Ethiopia. University of Applied Science, Cologne.

Anwar, M., Pawitan, H., Murtilaksono, K., \& Jaya, I.N.S. (2011). Respon hidrologi akibat deforestasi di DAS Barito Hulu, Kalimantan Tengah. Jurnal Manajemen Hutan Tropika, 17(3), 119126.

Arnold J.G., Moriasi, D.N, Gassman, P.W, Abbaspour, K.C., White, M.J., Srinivasan, R., Santhi, C., Harmel, R.D., van Griensven, A., van Liew, M.W., Kannan, N., \& Jha, M.K. (2012). SWAT: Model use, calibration and validation. Transaction of ASABE (American Society of Agricultural and Biological Engineers, 55(4), 1491-1508.

Badan Planologi Kehutanan. (2008). Pemantauan sumberdaya hutan, Pusat Inventarisasi dan Perpetaan Badan Planologi Kehutanan. Jakarta.

Dasanto, B.D, Pramudya, B, Boer, R., \& Suharnoto, Y. (2014). Effect of forest cover change on flood characteristics in the Upper Citarum Watershed. Jurnal Manajemen Hutan Tropika, 20(3), 141-149.
Dehmi, F., Burguete, J., \& Skhiri, A. (2012). SWAT application in intensice irrigation systems: Model modification, calibration and validation. Journal of Hydrology 470-471, 227-238. DOI: dx.doi.org/10.1016/j.jhydrol.2012. 08.055

Fajri, M., Fauzi, M., \& Sandhyavitri, A. (2016). Evaluasi kinerja DAS dan simulasi konservasi menggunakan SWAT (Soil and Water Assessment Tool) (Studi kasus: Sub DAS Tapung, Siak, Provinsi Riau). Jom FTEKNIK, 3(1), 111.

Freitas, S.R., Hawbaker, T.J., \& Metzeger, J.P. (2010). Effects of roads, topography, and land use on forest cover dynamics in the Brazilian Atlantic Forest. Forest Ecology and Management, 259, 410-417.

James, L.A. \& Lecce, S.A. (2013). Impacts of land-use and land-cover change on river systems. Treatise on Geomorphology, 9, 768-792. DOI: 10.1016/B978-0-12-374739-6.00264-5

Jones, J.A., Achterman, G.I., Augustine, L.A, Creed, I.F, Ffolliott, P.F, MacDonald, L., \& Wemple, B.C. (2009). Hydrologic effects of a changing forested landscape - challenges for the hydrological sciences. Hydrol. Process, (23), 2699-2704. DOI: 10.1002/hyp.7404.

Junaedi, E., \& Tarigan, S.D. (2012). Penggunaan model hidrologi SWAT (Soil and Water Assessment Tool) dalam pengelolaan DAS Cisadane. Jurnal Penelitian Hutan dan Konservasi Alam, 9(3), 221-237.

Kabupaten Asahan. (2013). Rencana tata ruang wilayah Kabupaten Asahan 2011-2030. Kisaran.

Lin, Y., Hong. N., Wu, P., Wu, C., \& Verburg, P.H. (2007). Impacts of land use change scenarios on hydrology and land use patterns in the WuTu watershed in Northern Taiwan. Landscape and Urban Planning, 80, 111-126.

Moriasi D.N., Arnold, J.G., Van Liew, M.W., Bingner, R.L., Harmel, R.D., \& Veith, T.L. (2007). Model evaluation guidelines for systematic quantification of accuracy in watershed simulations. Transaction of the ASABE, 50(3), 885-900.

Mubarok, Z., Murtilaksono, K., \& Wahjunie, E.D. (2015). Kajian respons perubahan penggunaan lahan terhadap karakteristik hidrologi DAS Way Betung, Lampung. Jurnal Penelitian Kehutanan Wallacea, 4(1), 1-10.

Nobert, J., \& Jeremiah, J. (2012). Hydrological respinse of watershed sistem to land use/cover change. Acase of Wami River Basin. The Open Hydrology Journal, 6, 78-87. 
Nyeko, M., D'Urso, G., \& Immerzeel, W.W. (2012). Adaptive simulation of the impact of changes in land use on water resources in the lower Aswa basin. Journal of Agricultural engineering, 42, e24.

Ozturk, M., Copty, N.K., \& Saysel, A.K. (2013). Modeling the impact of land use change on the hydrology of a rural watershed. Journal of Hydrology, 497, 97-109.

Pike R.G., Feller, M.C., Stednick, J.D., Rieberger, K.J., \& Carver, M. (2010). Water quality and forest management. In: Pike, R.G., Redding, T.E., Moore, R.D., Winkler, R.D., \& Bladon, K.D. (Editors). 2010. Compendium of Forest Hydrology and Geomorphology in British Columbia, 2(2). B.C. Min For. Range. For. Sci. Prog. Victoria BD and FORREX Forum for Research and Extention in Natural Resources Kamloops, BC. Land manag. Handb. 66.

Prasena, A., \& Shrestha, D.B.P. (2013). Assessing the effect of Land Use Change on Run Off in Bedog Sub Watershed Yogyakarta. Indonesian Journal of Geography, 45(1), 48-61.

Winkler, R.D., Moore, R.D., Redding, T.D., Spittlehouse, D.L., Smerdon, B.D., \& Carlyle-
Moses, D.E. (2010). The effect of forest disturbance on hydrologic processes and watershed response. In: Pike, R.G., Redding, T.E., Moore, R.D., Winkler, R.D., \& Bladon, K.D. (Editors). 2010. Compendium of Forest Hydrology and Geomorphology in British Columbia, 1 (2). B.C. Min For. Range. For. Sci. Prog. Victoria BD and FORREX Forum for Research and Extention in Natural Resources Kamloops, BC. Land manag. Handb. 66.

Yustika, R.D. (2013). Pengelolaan lahan terbaik hasil simulasi model SWAT untuk mengurangi aliran permukaan di Sub DAS Ciliwung Hulu. Thesis. Sekolah Pasca Sarjana IPB.

Yusuf, S.M. (2010). Kajian respon perubahan penggunaan lahan terhadap karakteristik hidrologi pada DAS Cirasea menggunakan model MWSAT. Thesis. Sekolah Pasca Sarjana IPB.

Zhang M., \& Wei, X. (2012). The cumulative effects of forest disturbance on streamflow in a large watershed in the central interior of British Columbia, Canada. Hydrol. Earth Syst. Sci. Discuss, 9, 2855-2895. DOI: 10.5.194/hessed9-2855-2012. 